\title{
Titik Beranjak Nurcholish Madjid: Dari Masa Kanak-kanak Sampai Tradisi Pesantren
}

\author{
Ahmad Gaus AF \\ Anggota Nurcholish Madjid Society dan mantan aktivis GMNI
}

\begin{abstract}
Abstarct: Nurcholish Madjid was a prominent Indonesian Muslim intellectual. Early in his academic career, Nurcholish was a leader in various student organizations. He soon became well known as a proponent for modernization within Islam. Throughout his career he continued to argue that for Islam to be victorious in the global struggle of ideas, it needs to embrace the concepts of tolerance, democracy and pluralism.
\end{abstract}

Kata Kunci: Nurcholish Madjid, Pesantren

\section{Pendahuluan}

Nama pertama yang diberikan pasangan $\mathrm{H}$. Abdul Madjid dan $\mathrm{Hj}$. Fathonah kepada putra sulungnya adalah Abdul Malik, yang berarti "hamba Allah" (Malik merupakan nama sebutan untuk Allah dalam deretan ketiga Asmaul Husna, nama-nama Allah yang Indah). Perubahan nama menjadi Nurcholish Madjid terjadi pada usia 6 tahun karena Abdul Malik kecil sering sakit-sakitan. Dalam tradisi Jawa, anak yang sering menderita sakit dianggap "kabotan jeneng" (keberatan nama), dan karena itu perlu ganti nama. Alasan lain perubahan nama itu adalah keinginan dari Abdul Malik sendiri. Sewaktu mulai diajari mengaji oleh ibunya, dan membaca surat al- Fatihah, ia selalu minta agar kata 'maliki' (yawmiddin) dalam surat itu diloncati saja: "Mak, nggak atik maliki-maliki Mak!" (Mak, tidak usah pakai 'maliki-maliki' Mak). Pemberian nama Nurcholish sendiri tidak terlalu jelas asal-muasalnya, kecuali bahwa nama itu dari kata Arab, nur berarti "cahaya" dan cholish berarti "murni" atau "bersih". Sementara itu nama belakangnya, Madjid, diambil dari nama belakang sang ayah.

Nurcholish lahir di lingkungan keluarga pesantren. Ayahnya, H. Abdul Madjid, adalah santri dari tokoh pendiri NU (Nahdlatul Ulama), Hadratusy Syaikh Hasyim Asy'ari di Pesantren Tebu Ireng, Jombang. Lebih dari sekadar santri, Abdul Madjid adalah santri yang sangat dipercaya oleh Kiai Hasyim lantaran prestasi belajarnya, terutama di bidang tata bahasa Arab (nahwu-sharaf) dan ilmu hisab atau ilmu hitung. Ketika menjadi santri Tebu Ireng, Kiai Hasyim memberinya nama Muhammad Thahir. Nama Abdul Madjid digunakan setelah pulang menunaikan ibadah haji pada 1927. Hubungan keduanya memang seperti anak dan bapak. Abdul Madjid, misalnya, kerap diminta oleh Kiai Hasyim untuk mengambilkan uang dari kantung jas di kamar sang Kiai. Ini hal yang tidak biasa, terutama bagi orang Jawa, dan hanya bisa terjadi karena kedekatan pribadi. Di lain waktu, Abdul Madjid juga sering terlihat sedang memijat tubuh sang Kiai.

Karena kedekatan pribadi itu pula, Kiai Hasyim menjodohkan Abdul Madjid dengan cucunya sendiri, Halimah. Ikatan perkawinan itu berlangsung selama dua belas tahun, namun tidak dikaruniai anak. Akhirnya mereka berpisah. Kiai Hasyim lalu menjodohkan Abdul Madjid dengan Fathonah, putri Kiai Abdullah Sajad, pendiri Pesantren Gringging, Kediri, Jawa Timur. Fathonah adalah adik dari Imam Bahri, santri Kiai Hasyim di Pesantren Tebu Ireng. Melalui Imam Bahri inilah Kiai Hasyim mengatur perjodohan Abdul Madjid dan Fathonah.

Menginjak tahun kedua pernikahan Abdul Madjid dan Fathonah, lahirlah 
Konfrontasi: Jurnal Kultur, Ekonomi dan Perubahan Sosial, 5 (1) January 2018, 50-59

P-ISSN: 1410-881X (Print)

Ahmad Gaus AF, Titik Beranjak Nurcholish Madjid: Dari Masa Kanak-kanak Sampai Tradisi

Pesantren

DOI: -

http://www.konfrontasi.net/index.php/konfrontasi2

Nurcholish, pada Jumat Legi, tanggal 17 Maret 1939. Belum genap berusia dua tahun Nurcholish memiliki adik perempuan yang bernama Radliyah atau Mukhlishah. Setelah itu menyusul adik perempuannya yang lain yang bernama Qoni'ah (meninggal pada usia 15 tahun akibat penyakit malaria tropika), kemudian berturut-turut lahir Saifullah Madjid dan Muhammad Adnan. Seperti halnya Nurcholish, kedua adik laki-lakinya ini juga disekolahkan di pesantren Gontor. Hanya saja, berbeda dengan Nurcholish yang menapaki jalur keilmuwan, atau Mukhlisah yang menjadi guru, Saifullah Madjid dan Muhammad Adnan memilih jalur bisnis setelah lulus kuliah.

\section{Lingkungan Sosial}

Meski terdidik secara santri, keluarga H. Abdul Madjid tidak tinggal di lingkungan pesantren. Ketika Nurcholish lahir di Mojoanyar, Kecamatan Bareng, Kabupaten Jombang, kawasan ini masih didominasi kaum abangan (kaum Muslim yang tidak menjalankan syariat Islam). Pada 1946, H. Abdul Madjid mendirikan Madrasah Diniyah al-Wathaniyahsekolah Islam pertama di desa ini. Al-Wathaniyah secara harfiah berarti "patriotisme", karena didirikan pada masa revolusi. Madrasah inilah yang mengawali terbentuknya tradisi pendidikan Islam di Kecamatan Bareng.

Di daerah-daerah lain di Jombang, tradisi pendidikan Islam saat itu telah tumbuh subur dengan adanya empat pesantren besar: Pesantren Bahrul Ulum di Tambak Besar, Kecamatan Jombang (didirikan pada 1838), Pesantren Darul Ulum di Rejoso, Kecamatan Peterongan (didirikan pada 1885), Pesantren Tebuireng di Tebu Ireng, Kecamatan Diwek (didirikan pada 1899), dan Pesantren Manbaul Maarif di Denanyar, Kecamatan Jombang (didirikan pada 1917). Keterlambatan wilayah Bareng dalam mengadopsi sistem pendidikan Islam disebabkan oleh kenyataan bahwa kultul keislaman di wilayah ini-dan sebenarnya juga di seluruh daerah Jombang-pada masa lalu tidak terlalu dominan. Kendatipun Islam dipeluk oleh mayoritas penduduk Bareng, namun sebagian besar mereka adalah abangan. Selain itu, agama-agama Kristen, Hindu, Buddha, dan Konghucu juga mendapatkan tempat setara di Bareng dan, secara lebih luas, Jombang, dengan latar belakang sejarah yang panjang, yaitu kolonialisme (Kristen), kerajaan Majapahit (Hindu-Budha), dan gelombang kedatangan orang-orang dari daratan China pada abad KE-16 (Konghucu).

Dengan latar belakang seperti itu, kehidupan keagamaan di Jombang secara keseluruhan tumbuh dalam suasana kemajemukan. Dalam sejarah Jombang tidak pernah tercatat kekerasan atas nama agama yang melibatkan massa. Di kalangan pemeluk Islam sendiri yang merupakan mayoritas penduduk Jombang, polarisasi antara kaum santri dan abangan tidak pernah menimbulkan masalah. Orang Jombang pada umumnya percaya bahwa kata Jombang berasal dari istilah Jawa, ijo dan abang; ijo atau hijau mewakili kaum santri, dan abang atau merah mewakili kaum abangan. Untuk menghindari pengertian negatif dari "abangan", kata ini juga kerap diasosiasikan dengan kaum nasionalis. Warna hijau (santri) dan merah (nasionalis) kemudian menjadi warna dasar lambang Kabupaten Jombang, hingga sekarang.

Kelompok "hijau" yang menyebar di kantong-kantong pesantren yang tumbuh kian subur membentuk citra Jombang sebagai kota santri. Penyebaran pengaruhnya pun sangat luas jika dilihat dari kenyataan bahwa semua pendiri pesantren di Jawa pernah menuntut ilmu di kota ini. Sementara itu, kelompok "merah" juga tidak selalu identik dengan citra yang buruk. Dari tangan merekalah, misalnya, lahir kesenian rakyat yang disebut besutan (atau teater jalanan), 
Konfrontasi: Jurnal Kultur, Ekonomi dan Perubahan Sosial, 5 (1) January 2018, 50-59

P-ISSN: 1410-881X (Print)

Ahmad Gaus AF, Titik Beranjak Nurcholish Madjid: Dari Masa Kanak-kanak Sampai Tradisi

Pesantren

DOI: -

http://www.konfrontasi.net/index.php/konfrontasi2

yang kemudian lebih dikenal dengan nama ludruk.

Jombang pada masa lalu adalah pintu masuk menuju Kerajaan Majapahit (12931500 M). Tidak heran banyak desa/kota di Jombang dimulai dengan awalan mojo, seperti Mojoagung, Mojowarno, Mojojejer, Mojotengah, Mojongapit, termasuk Mojoanyar, kecamatan Bareng, tempat kelahiran Nurcholish Madjid. Bahkan di Bareng terdapat sebuah candi peninggalan Majapahit, yaitu candi Arimbi.

Islamisasi Jombang merupakan pengaruh dari perluasan Kerajaan Mataram Islam yang berpusat di Kotagede, yang berdiri pada abad KE-16, menyusul runtuhnya Majapahit. Meskipun proses Islamisasi berlangsung nyaris tuntas $(98 \%$ penduduk Jombang memeluk Islam), namun tidak seluruh penduduknya tersantrikan. Sebagian di antara mereka masih memegang filosofi Jawa atau Kejawen, yang dikawinkan dengan ajaran Islam sehingga disebut Islam-Kejawen atau Islam Jawa. Kelompok inilah yang disebut oleh antropolog Clifford Geertz sebagai Islam abangan itu.

Namun demikian, dikotomi Islam santri dan Islam abangan sebenarnya hanya ada dalam tataran konseptual. Dalam kenyataannya, keduanya berinteraksi secara luwes dan dikondisikan untuk bersikap moderat. Yang tidak ditolerir oleh kaum santri adalah subkultur kaum abangan yang bertentangan dengan ajaran Islam seperti perjudian, minuman keras, dan pelacuran yang terkonsentrasi di daerah-daerah tertentu yang kemudian disebut "daerah hitam". Bentuk perlawanan kaum santri terhadap subkultur ini adalah mengubah daerah hitam menjadi kawasan religius. Itulah alasannya mengapa pesantren-pesantren di Jombang berdiri di kawasan yang dulunya merupakan daerah hitam.

Secara sosio-kultural, pengaruh Mataram tidak hanya muncul dalam bentuk penyebaran Islam, tapi juga dalam tutur kata. Bahasa orang Jombang sebagian dipengaruhi oleh dialek Mataraman yang berakar pada bahasa Jawa Pertengahan dengan ciri utama adanya tingkatan atau hirarki yang mengindikasikan feodalisme. Sementara sebagian yang lain sangat kental dengan dialek Surabaya yang lebih egaliter. Penyebutan "Mas" kepada orang yang lebih tua, dalam dialek Surabaya diganti dengan "Cak", sehingga lebih mengesankan kesetaraan. Keluarga Nurcholish hidup dalam kultur Surabayaan ini. Ayahnya, misalnya, lebih senang berdialog dengan anak- anaknya ketimbang memaksakan kehendak sebagaimana menjadi obsesi orang-orang tua feodal. Karena itu, ia tenang-tenang saja ketika anak perempuannya, Mukhlishah, menolak untuk dijodohkan. Dalam soal pembagian waris, ia malah melampaui ide kesetaraan. Anak perempuannya justru mendapatkan lebih banyak dari anak laki-laki. Adikadik Nurcholish juga memanggil dirinya dengan sebutan Cak, bukan Mas.

\section{Cita-cita Masa Kecil}

Madrasah al-Wathaniyah didirikan oleh H. Abdul Madjid untuk mengimbangi pendidikan sekular (Sekolah Rakyat/SR). Ketiadaan lembaga pendidikan agama menjadi alasan anak-anak muda di sini mewarisi kebiasaan mabuk dan berjudi. $\mathrm{H}$. Abdul Madjid mengambil tanggung jawab pendidikan anak-anak Islam ke pundaknya. Mulamula, pendidikan agama dilakukan secara semi formal di dalam mushala yang masih berupa papan dan anyaman bambu. Baru pada 1947 ia mendirikan bangunan alWathaniyah di atas lahan kosong miliknya, di bawah naungan Yayasan Wakaf Umat Sejahtera yang juga ia didirikan bersama Kyai Abdul Mukti.

Madrasah al-Wathaniyah pada awalnya merupakan sekolah pelengkap untuk membekali anak-anak dengan pendidikan agama yang memadai, yang tidak didapat di SR. Untuk tujuan 
Konfrontasi: Jurnal Kultur, Ekonomi dan Perubahan Sosial, 5 (1) January 2018, 50-59

P-ISSN: 1410-881X (Print)

Ahmad Gaus AF, Titik Beranjak Nurcholish Madjid: Dari Masa Kanak-kanak Sampai Tradisi

Pesantren

DOI: -

http://www.konfrontasi.net/index.php/konfrontasi2

itu, Nurcholish mengenyam pendidikan rangkap. Pagi hari ia sekolah di SR, dan sore harinya belajar di Madrasah al- Wathaniyah. Guru-guru di SR semuanya beragama Kristen. Karena itu salah seorang pamannya pernah melarang Nurcholish belajar di SR. Tapi itu tidak memberikan solusi. Arus pendidikan sekular berusaha diimbangi dengan mendirikan Al-Wathaniyah, tanpa berusaha untuk menyainginya.

Atas pertimbangan itu, H. Abdul Madjid tetap membiarkan Nurcholish belajar di SR. Bagaimanapun, ia menganggap pengetahuan umum tetap penting. Ia juga tidak melihat anaknya kesulitan menerima pelajaran pagi dan sore hari. Ini terlihat dari nilai-nilainya yang rata-rata baik, terutama ilmu hitung atau aljabar yang selalu mendapat nilai tinggi. Pada saat yang sama, Nurcholish juga mampu dengan mudah menguasai pelajaran di madrasah seperti tata bahasa Arab (nahw dan sharaf). Di SR Nurcholish diajari ilmu bumi, dan ia mampu menggambar peta Jawa Timur lengkap dengan letak kota-kotanya tanpa melihat atlas. Dan pada saat yang sama, ia juga tidak kesulitan menghapal beberapa kitab berbahasa Arab seperti 'Aqîdah al-`Awwâm dan `Imrîthî.

H. Abdul Madjid praktis tidak punya alasan untuk memilihkan salah satu dari dua sekolah tersebut untuk Nurcholish. Ia juga tidak pernah mengekang anaknya untuk bergaul dan bermain sebagaimana layaknya anak-anak sebaya dia. Teman masa kecil Nurcholish, Ahmad Kholil, menuturkan, permainan yang sangat disukai Nurcholish ialah membuat saluran-saluran air di sawah, menyusuri rel kereta, dan bermain kapal-kapalan terbang. Saat bermain kapal terbang, Nurcholish membedakan konstruksi pesawat dari masing-masing negara. Kapal terbang Inggris dibuat dalam ukuran sedang dan diberi warna merah; kapal terbang Jepang dibuat dalam ukuran lebih kecil, sementara kapal terbang Amerika dibuat dalam ukuran lebih besar dan dilumurinya dengan kapur putih. Di hari lain, ketika lelah menyusuri rel-rel kereta, ia berhenti di stasiun. Kekagumannya tertuju pada sang masinis kereta karena sanggup menggerakkan rangkaian gerbong yang begitu panjang. Ketika ditanya oleh gurunya di SR apa cita-citanya, Nurcholish menjawab ingin menjadi masinis kereta-suatu cita-cita yang tidak lazim karena pada masa itu umumnya anak-anak bercita-cita menjadi guru atau tentara.

Nurcholish kecil adalah pribadi pendiam. Jika tidak sedang berhasrat untuk bermain, ia duduk di bawah pohon dan mengeluarkan secarik kertas berisikan catatan pelajaran. Ketika teman-temannya satu persatu mengerubunginya, ia menciptakan suasana belajar dengan menanyakan kepada mereka satu orang satu pertanyaan, dan membetulkannya jika ada yang salah. Setelah itu mereka berlarian ke tepi sungai untuk menabur dedak di sekitar wuwu (alat penjaring ikan yang terbuat dari bambu). Esok harinya, sehabis subuh, mereka kembali ke tepi sungai untuk mengangkut ikan yang tersangkut pada wuwu.

\section{Pusat Pendidikan Islam}

Nurcholish adalah murid pertama di Madrasah al-Wathaniyah yang didirikan oleh ayahnya. Di angkatannya, hanya tercatat tujuh orang siswa yang mendaftar pada tahun pertama. Namun perkembangan madrasah ini terbilang pesat. Hanya dalam waktu tiga tahun, tercatat seratusan orang siswa belajar di sini. Meski pendidikan Islam yang dikembangkan oleh $\mathrm{H}$. Abdul Madjid di sini bercorak NU, ditandai dengan pendidikan kitab kuning (kitab klasik), dan dia sendiri lulusan pesantren NU (Tebu Ireng), namun dia tidak memasang papan nama NU. Banyak anak-anak dari orang tua yang bersimpati kepada Muhammadiyah belajar di sini.

Ibunda Nurcholish, Hj. Fathonah, juga tidak berdiam diri. Ia mengambil alih tugas mendidik kaum perempuan di Mojoanyar. Awalnya ia mendengar laporan bahwa anak-anak 
Konfrontasi: Jurnal Kultur, Ekonomi dan Perubahan Sosial, 5 (1) January 2018, 50-59

P-ISSN: 1410-881X (Print)

Ahmad Gaus AF, Titik Beranjak Nurcholish Madjid: Dari Masa Kanak-kanak Sampai Tradisi

Pesantren

DOI: -

http://www.konfrontasi.net/index.php/konfrontasi2

perempuan di dusun ini tidak bisa membaca Alquran dan tidak mengerti tata cara wudlu dan salat. Jadilah ia kemudian turun tangan dan langsung mengajari mereka. Pengajaran itu berkembang ke bidang-bidang lain yang lebih luas, terutama ketentuan-ketentuan fikih yang terkait dengan kaum perempuan.

Pada saat lembaga pendidikan keagamaan di Jombang Selatan masih langka, dan mayoritas kaum Muslim adalah abangan dan pengikut Kejawen, keberadaan al-Wathaniyah bagaikan oase yang mengalirkan air ke tanah- tanah kering. Tidak berbilang tahun, madrasah ini menjadi pusat pendidikan Islam yang berwibawa. Partisipasi masyarakat tumbuh didorong oleh rasa memiliki yang kuat, lantaran keberadaan al-Wathaniyah berdampak nyata dalam kehidupan mereka. Ini terlihat ketika jalannya roda pendidikan mulai terseok karena salah satu penyokong dananya, Kyai Ilyas (kakak dari H. Abdul Madjid) meninggal dunia, dan H. Abdul Madjid menjadi satu-satunya penanggung biaya operasional pendidikan. Dengan segera masyarakat sekitar-yang kondisi perekonomiannya sebenarnya jauh dari cukupmengulurkan tangan secara bergotong royong untuk menyelamatkan lembaga pendidikan tersebut.

Nurcholish tamat dari SR ketika usianya sudah mencapai remaja, 14 tahun. Tapi ia tidak sendirian. Teman-teman sekampungnya seperti Muhid, Muksin, Anam, Muchamad Salim, Mochammad Iksan, Mian, dan Sanuji, juga menamatkan SR pada usia tersebut. Mereka pada umumnya terpaksa menunda sekolah karena suasana perang. Pertempuran antara Belanda melawan Jepang menjelang kemerdekaan RI pada 1945 tak jarang terjadi di desa mereka, menyebabkan warga mengungsi ke tempat-tempat aman. Kehidupan tidak menentu, dan anak-anak menjadi korbannya karena harus ikut keluarga mengungsi. Begitu juga keluarga H. Abdul Madjid. Walhasil, Nurcholish baru masuk sekolah pada usia 9 tahun.

\section{Tradisi Pesantren}

Tamat dari SR pada 1953, Nurcholish dimasukkan oleh ayahnya ke Pesantren Darul Ulum, yang lebih dikenal dengan nama Pesantren Rejoso, karena terletak di Desa Rejoso, Kecamatan Peterongan. Ia tidak dikirim ke Pesantren Tebu Ireng, almamater ayahnya dulu, karena pengasuh pesantren tersebut, KH Hasyim Asy’ari, telah wafat. Pesantren Rejoso saat itu diasuh oleh Kiai Romli Tamim dan KH Dahlan Cholil. Kiai Romli tidak lain adalah kawan dekat ayah Nurcholish, H. Abdul Madjid, ketika keduanya sama-sama menjadi santri KH Hasyim Asy'ari di Tebu Ireng. Dengan memasukkan Nurcholish ke Pesantren Rejoso, sebenarnya H. Abdul Madjid menitipkan anaknya itu kepada temannya sendiri, Kiai Romli.

Adapun KH Dahlan Cholil ialah putra KH Cholil, salah satu pendiri Pesantren Rejoso. Ia juga pernah belajar kepada KH Hasyim Asy'ari di Pesantren Tebu Ireng. Setelah lulus ia melanjutkan sekolah ke Mekah. Pada 1932 ia pulang ke Rejoso dan menjadi penerus pesantren yang didirikan ayahnya tersebut. Pada 1933 ia memberi nama pesantren itu Pesantren/Madrasah Darul Ulum, nama yang sama dengan madrasah di Mekah di mana ia menjadi salah satu perintisnya.

Ketika masuk ke Pesantren Rejoso atau Darul Ulum, Nurcholish diterima di kelas enam tingkat Ibtidaiyah. Ia melompati kelas lima karena semua mata pelajarannya telah ia kuasai semenjak duduk di bangku madrasah milik ayahnya, al-Wathaniyah. Pelajaran di kelas enam pun pada dasarnya hanya mengulang pelajaran di al-Wathaniyah, sehingga ia 
Konfrontasi: Jurnal Kultur, Ekonomi dan Perubahan Sosial, 5 (1) January 2018, 50-59

P-ISSN: 1410-881X (Print)

Ahmad Gaus AF, Titik Beranjak Nurcholish Madjid: Dari Masa Kanak-kanak Sampai Tradisi

Pesantren

DOI: -

http://www.konfrontasi.net/index.php/konfrontasi2

dengan mudah menamatkan belajarnya, dan kemudian melanjutkan ke tingkat Tsanawiyah pada 1954, di pesantren yang sama. Hal yang baru bagi Nurcholish ialah bahwa ia menetap di asrama dan menghirup tradisi pesantren secara penuh.

Sebagai lembaga pendidikan yang berumur cukup tua (berdiri sejak $1885 \mathrm{M}$ ), Pesantren Rejoso telah memiliki tradisi yang mapan, terutama dipengaruhi oleh otoritas keilmuan para pengasuhnya. Kiai Romli dikenal sebagai ahli tasawuf dan mursyid tarekat Qadiriyah-Naqsabandiyah. Sedangkan Kiai Dahlan dikenal sebagai ahli tafsir sekaligus hafidz (penghafal) Alquran. Dengan menggabungkan keduanya, para santri alumni pesantren ini diharapkan akan menjadi salikin (praktisi tarekat) dan hafidz sekaligus mufasir Alquran.

Selain berada di pundak para kiai, sumber tradisi Pesantren Rejoso juga berpusat di masjid. Waktu-waktu salat merupakan saat dimana para santri bertatap muka secara akrab dengan para kiai. Santri diwajibkan melakukan salat lima waktu di masjid. Para kiai bergiliran menjadi imam, dan setelah itu menyampaikan taushiyah (nasihat agama) sesuai bidang keahlian. Kiai Romli yang mursyid tarekat dan bertugas menjadi imam salat Subuh, menyampaikan pengajian tasawuf bakda salat. Begitu pula Kiai Dahlan yang ahli tafsir dan mendapat giliran menjadi imam salat Isya, menyampaikan pengajian tafsir seusai salat. Kedekatan kiai dan santri terjalin sangat akrab. Dan menurut Nurcholish, momen-momen seperti ini sangat berkesan di hati para santri, termasuk dirinya, sehingga nasihat para kiai pun menjadi mudah diterima. Sampai dewasa ia mengaku masih mengingat dengan jelas ajaranajaran kiai yang disampaikan di masjid usai salat.

Pada tahun pertama, Nurcholish sangat menikmati kegiatan belajar. Sebagian besar karena ia telah dibekali pengetahuan dasar di Madrasah al- Wathaniyah dengan kitab-kitab standar seperti Jurumiyah, Imrithi, Tuhfatul Athfal, dan Aqidatu Awwam. Karena itu ia relatif tidak mendapat kesulitan ketika harus berhadapan dengan kitab-kitab lanjutan seperti Alfiyah, Bad'ul Mal, Jauharatut Tauhid, dan lain-lain. Nurcholish juga aktif dalam kegiatan-kegiatan ekstra kurikuler, bahkan pernah menjadi juara satu lomba pidato bahasa Indonesia saat duduk di bangku kelas satu Tsanawiyah. Pergaulan dengan teman-teman baru pada umumnya tidah ada masalah. Yang sangat mengganggunya ialah kondisi kamar. Ia tidak cukup kerasan untuk tidur di kamar pondokan yang kecil, yang satu kamarnya diisi sampai lima belas orang santri. Maka, hampir setiap malam ia membawa bantal dan selimut ke masjid untuk tidur karena di kamar tidak kebagian tempat.

\section{NU versus Masyumi}

Suasana politik menjelang pemilu 1955 sangat terasa di desa-desa. Partai- partai kaum santri yang diwakili oleh NU dan Masyumi berusaha menarik dukungan dari kantong-kantong Islam di Jombang. NU telah keluar dari Masyumi dalam Muktamar Palembang (1952) dengan aroma konflik yang tidak bisa ditutup-tutupi. Oleh sebab itu, persaingan NU dan Masyumi di tingkat pusat merembes ke desa-desa tempat kedua partai ini membangun basis dukungan.

Pesantren Rejoso yang berorientasi NU tidak imun dari kepentingan politik untuk membentengi pengaruh Masyumi yang cukup kuat di desa-desa. Dalam menghadapi persaingan dengan NU, Masyumi cukup diuntungkan karena KH Hasyim Asy'ari pernah menjadi Rais Akbarnya, sehingga legitimasi politik dari pendiri NU tersebut terus diekspose kalangan Masyumi untuk meraih suara kaum Nahdliyin. Ayah Nurcholish sendiri, H. Abdul 
Konfrontasi: Jurnal Kultur, Ekonomi dan Perubahan Sosial, 5 (1) January 2018, 50-59

P-ISSN: 1410-881X (Print)

Ahmad Gaus AF, Titik Beranjak Nurcholish Madjid: Dari Masa Kanak-kanak Sampai Tradisi

Pesantren

DOI: -

http://www.konfrontasi.net/index.php/konfrontasi2

Madjid, adalah pendukung Masyumi yang setia, karena berpegang pada apa yang diyakininya sebagai "fatwa" dari KH Hasyim Asy'ari bahwa Masyumi merupakan satusatunya partai Islam. Sampai wafatnya pada 1947, ia tidak pernah mendengar Kiai Hasyim mencabut "fatwa" tersebut, sehingga ia tetap mendukung Masyumi. Masjid di kampungnya pun diklaim sebagai masjid Masyumi. Bahkan Ibunda Nurcholish, $\mathrm{Hj}$, Fathonah, aktif menjadi juru kampanye partai tersebut menjelang pemilu 1955. Akan tetapi, dampak dari sikap politik orangtuanya itu segera terasa oleh Nurcholish. Saat belajar, ia sering disindir oleh para pengajar sebagai anak Masyumi yang kesasar (di sarang NU).

Mendekati pelaksanaan pemilu, pertentangan politik antara NU dan Masyumi kian memanas di kalangan masyarakat bawah. Retorika kampanye muncul dalam bentuk sindiran dan ejekan. Forum-forum keagamaan dimanfaatkan oleh aktivis-aktivis NU untuk menyerang Masyumi. Begitu juga sebaliknya. Sindiran terhadap Nurcholish pun makin sering dilakukan oleh anak-anak NU di Pesantren Rejoso, sehingga ia mulai merasa tidak betah. Suatu ketika ia pulang kampung, dan menceritakan semua kejadian itu kepada ayahnya.

H. Abdul Madjid menanggapi apa yang dialami Nurcholish sebagai sesuatu yang serius, sehingga ia memutuskan untuk menarik anaknya dari Pesantren Rejoso. Ketika keputusan itu disetujui oleh istrinya, ia lalu memindahkan Nurcholish ke Pesantren Gontor, Ponorogo, Jawa Timur. Keputusan H. Abdul Madjid itu membuat heran banyak orang di kampungnya, sebab di mata mereka (dan di mata kaum Nahdliyin Jombang pada umumnya) saat itu Pesantren Gontor memiliki citra "setengah kafir". Setidaknya, ia dianggap bukan pesantren NU, melainkan pesantren Masyumi. Belakangan, setelah belajar dan tinggal di Gontor, Nurcholish tahu bahwa pesantren ini bukan pesantren Masyumi. Para guru dan siswanya datang dari berbagai latar belakang kultur keagamaan. Bahkan para pendirinya pun (K.H. Ahmad Sahal, K.H. Imam Zarkasyi, dan K.H. Zainuddin Fanani) bukan orang-orang Masyumi.

\section{Falsafah Pendidikan Gontor}

Pesantren Gontor (didirikan pada 1926) adalah pesantren bercorak modern. Salah satu indikasinya ialah penggunaan bahasa asing selain bahasa Arab yang diwajibkan, yakni bahasa Inggris. Bahkan di masa kolonial, bahasa Belanda dan Jepang juga menjadi mata pelajaran wajib. Kiai Zarkasyi sendiri, salah seorang pendiri Pesantren Gontor, pernah belajar di Pesantren Tegalsari, Ponorogo, yang melahirkan pujangga kenamaan Ronggowarsito. Namun, pandangan-pandangan Kiai Zarkasyi lebih banyak dibentuk ketika ia belajar kepada Mahmud Yunus di Sekolah Noormal Islam, Padang Panjang, Sumatera Barat.

Mahmud Yunus adalah lulusan al-Azhar dan Darul Ulum (keduanya di Mesir), dengan spesialisasi bidang ilmu kependidikan. Sepulang dari Mesir pada 1929 ia mendirikan KMI (Kuliyyat-u 'l-Mu allimîn al-Islâmiyyah) di Padang Panjang. Di sinilah Imam Zarkasyi belajar sampai tahun 1935. Ketika pulang ke Pesantren Gontor ia melakukan perombakan kurikulum dan metode pengajaran pesantren ini menjadi lebih modern, disamakan dengan yang didapatkannya di Padang Panjang. Ia membuka dan menangani sendiri program pendidikan baru tingkat menengah pertama dan menengah atas yang dinamakan Kulliyatul Mu'allimin al-Islamiyyah (KMI) atau Sekolah Guru Islam pada tanggal 19 Desember 1936. Dalam program ini kurikulum agama dan umum diberikan secara seimbang selama 6 tahun (gabungan tingkat SMP dan SMA yang masing-masing 3 tahun). Selain itu, juga diberikan pendidikan ekstra kurikuler untuk membekali pengalaman siswa seperti pendidikan ketrampilan, kesenian, olahraga, organisasi, pramuka, latihan berpidato, dan 
Konfrontasi: Jurnal Kultur, Ekonomi dan Perubahan Sosial, 5 (1) January 2018, 50-59

P-ISSN: 1410-881X (Print)

Ahmad Gaus AF, Titik Beranjak Nurcholish Madjid: Dari Masa Kanak-kanak Sampai Tradisi

Pesantren

DOI: -

http://www.konfrontasi.net/index.php/konfrontasi2

lain-lain.

Citra pesantren "setengah kafir" yang dituduhkan kepada Gontor bermula dari pengajaran bahasa Belanda dan bahasa Inggris yang memang masih dianggap sebagai bahasa orang kafir. Mata pelajaran umum dan sistem kelas yang diterapkan di pesantren ini juga menjadi cemooh masyarakat ketika itu. Terlebih lagi para santri memakai celana panjang dan dasi, berbeda dengan santri ketika itu yang lazimnya memakai sarung dan peci. Tidak heran jika pembukaan program ini kurang mendapat sambutan, bahkan jumlah santri Gontor saat itu sempat merosot tajam dari ratusan menjadi beberapa belas orang saja. Namun para pengasuh pesantren tidak patah semangat. "Biarpun tinggal satu orang santri, program ini akan tetap akan kami jalankan sampai selesai," ujar Kiai Zarkasyi. Dan ia telah membuktikan bahwa tekadnya benar.

Pembaruan juga dilakukan dalam pengajaran bahasa. Seperti halnya KMI Padang Panjang, Pesantren Gontor tak hanya menekankan penguasaan bahasa Arab, namun juga menunjukkan bagaimana secara didaktis-metodis modern para siswa menguasai bahasa tersebut dengan cepat dan mudah. Begitu juga pengajaran bahasa Inggris yang menggunakan buku Berlitz, yang berarti "katakan", dimana para siswa didorong untuk aktif berbahasa sehingga mereka cepat menguasai bahasa tersebut. "Belajar di Gontor itu memang seperti terbang, cepat sekali," ujar Nurcholish. Diduga bahwa sistem Berlirz ini diadopsi oleh Mahmud Yunus dari Mesir juga yang saat ia belajar di sana sedang musim kursus bahasa dengan sistem Berlitz.

Di Gontor tidak pernah ada isu pertentangan NU-Masyumi. Pilihan-pilihan materi pengajaran pada kitab-kitab yang tidak monolitik merupakan salah satu alasannya. Di sini, misalnya, diajarkan kitab karya filsuf dari Spanyol, Ibn Rusyd, Bidâyah al-Mujtahid. Kitab fikih klasik ini berwawasan perbandingan mazhab, sehingga mendorong para santri bersikap terbuka dan berjiwa bebas. Salah satu santri kebanggaan Kiai Zarkasyi ialah Idham Chalid yang kelak menjadi Ketua PB NU dan Ketua MPR. Suatu ketika saat ditanya wartawan darimana ia mendasarkan sumber pandangan keislamannya yang terbuka, ia menjawab, dari kitab Bidâyah al-Mujtahid. Nurcholish sendiri membentuk pandangan-pandangannya dari kitab yang mulai dipelajarinya di kelas lima itu. Ia juga sangat menyukai pelajaran Mahfudzat (ungkapanungkapan dalam bahasa Arab yang mengandung kearifan), Muthala'ah (cerita-cerita dalam bahasa Arab yang mengandung pelajaran hidup), al-Dinayah (agama-agama), dan Mantiq (Logika).

Tradisi Pesantren Gontor dibentuk oleh apa yang disebut Panca Jiwa Pondok yaitu: keikhlasan, kesederhanaan, berdikari, ukhuwah Islamiyah, dan jiwa bebas. Kelimanya menjadi sendi kehidupan para santri. Selain itu, pondok juga memiliki motto yang menjadi falsafah pendidikan dan pengajarannya, yaitu: berbudi tinggi, berbadan sehat, berpengetahuan luas, dan berpikiran bebas. Keempat unsur itu saling terkait satu sama lain. Unsur yang pertama menjadi dasar bagi unsur-unsur lainnya. Karena itu, misalnya, pengetahuan luas harus selalu dikaitkan dengan budi yang tinggi, dengan begitu para santri akan mengerti bahwa ilmu yang mereka miliki harus dimanfaatkan untuk tujuan kemaslahatan. Begitu juga motto "berpikiran bebas", harus didahului oleh pengetahuan yang luas, sehingga kebebasan berpikir itu benar-benar mencerminkan kematangan dan tidak menjurus ke arah pemujaan pada akal pikiran.

Salah satu wujud dari kebebasan berpikir itu ialah pilihan-pilihan pada mazhab (fikih). Dengan membiarkan para santri (dewasa) menentukan pilihan mereka sendiri dalam bermazhab, para pengasuh pesantren mendidik mereka untuk menghargai prinsip kebebasan. Para pengasuh pesantren, menurut Nurcholish, memang tidak menginginkan santri-santri mereka disibukkan oleh urusan-urusan khilafiyah dalam agama. Gontor, lanjutnya, ingin 
Konfrontasi: Jurnal Kultur, Ekonomi dan Perubahan Sosial, 5 (1) January 2018, 50-59

P-ISSN: 1410-881X (Print)

Ahmad Gaus AF, Titik Beranjak Nurcholish Madjid: Dari Masa Kanak-kanak Sampai Tradisi

Pesantren

DOI: -

http://www.konfrontasi.net/index.php/konfrontasi2

mencetak lulusan para calon pemimpin yang mampu mengatasi perbedaan-perbedaan dan sekaligus menjadi perekat dari perbedaan tersebut. Karena itu, sikap terbuka dan jiwa yang bebas, mendidik lulusan Gontor untuk bersikap lentur dalam menghadapi berbagai perbedaan.

\section{Belajar Mengarang}

Ketika masuk Pesantren Gontor, Nurcholish sebenarnya tertarik untuk belajar bahasa Arab dan Inggris. Tapi ia dimasukkan ke kelas ilmu pasti, meski tetap diajarkan bahasa. Kendati demikian ia menyukai semua pelajaran. Bahkan nilai ujian untuk pelajaran ilmu hitungnya selalu sepuluh. Yang paling tidak ia sukai ialah pelajaran mengarang (al-insya'). Ia menduga mengarang itu hanya mengkhayal. Karena tidak suka, maka ketika mengarang ia malas-malasan; hanya menterjemahkan beberapa bagian dari buku berbahasa Inggris. Namun dengan cara begitu ia justru memperoleh nilai yang tinggi. Gurunya pernah menegur apakah dia menerjemahkan dari bahasa Inggris, Nurcholish menjawab ya. Tapi guru itu membiarkan Nurcholish meneruskan cara tersebut, dan nilainya tetap tinggi. Sejak itu, Nurcholish sangat menyukai pelajaran mengarang, yang sedikit demi sedikit ia tingkatkan dengan mengarang dari pikirannya sendiri.

Berbagai fasilitas olahraga dan seni juga disediakan untuk para santri. Tapi Nurcholish hanya suka belajar, terutama belajar bahasa Arab, Inggris, dan Perancis. Hanya sesekali ia turun ke lapangan sepak bola, itu pun dengan posisi selalu di belakang, karena ia malas lari-larian. Nurcholish juga menyukai kesenian, khususnya musik dan drama yang berkembang pesat di pesantren Gontor. Tapi, lagi-lagi ia hanya menjadi penonton, karena merasa tidak berbakat menyanyi, apalagi bermain drama.

Bahasa Perancis sebenarnya tidak diajarkan secara resmi di Gontor. Nurcholish mempelajarinya di rumah seorang guru bahasa di Gontor, Muhammad Syarif, secara private. Rumah Syarif berada dekat sekali dengan pesantren, sehingga tidak sulit bagi Nurcholish dan teman-temannya yang lain memperoleh izin dari pihak pesantren untuk belajar di rumah Syarif. Apalagi, tawaran itu datang dari Syarif sendiri. Ketika duduk di kelas lima (setingkat dengan kelas dua SMA), ia sudah dapat membaca buku-buku berbahasa Perancis dengan bantuan kamus. Kelak, ketika kuliah di IAIN, ia melanjutkan memperdalam bahasa Perancis di Alliance Francais di Kedutaan Perancis. Salah seorang temannya di kelas ialah Rahmi Hatta.

\section{Perpustakaan Kiai}

Salah satu kesukaan Nurcholish ketika belajar di Gontor ialah berkirim surat kepada kedutaan-kedutaan besar asing di Jakarta. Dari mereka ia mendapat banyak buku berbahasa Inggris, seperti Hero with the Thousand Thesis dan Mysticism: East and West. Di Gontor bukannya tidak ada perpustakaan, malah cukup besar, tetapi entah kenapa, tidak bisa diakses oleh para santri. Itu yang menyulitkan Nurcholish menyalurkan hobi membaca yang telah ditanamkan oleh orangtuanya. Untuk bisa membaca koran dan majalah pun, santri Gontor harus berpatungan dengan para guru yang memiliki minat baca yang sama. Mereka berlangganan koran berbahasa Inggris yang terbit di Jakarta, Jakarta Time, dan majalah bulanan populer berbahasa Inggris, Reader's Diggest.

Sementara perpustakaan pesantren tertutup untuk para santri, tidak demikian dengan perpustakaan pribadi Kiai Zarkasyi. Ia malah selalu mengundang para santri kelas lima dan enam, dan memberi tugas untuk membaca buku-buku tertentu, sebagian besar kitab-kitab dalam bahasa Arab. Buku-buku itu ia pinjamkan kepada para santri untuk dibaca, dan pada 
Konfrontasi: Jurnal Kultur, Ekonomi dan Perubahan Sosial, 5 (1) January 2018, 50-59

P-ISSN: 1410-881X (Print)

Ahmad Gaus AF, Titik Beranjak Nurcholish Madjid: Dari Masa Kanak-kanak Sampai Tradisi

Pesantren

DOI: -

http://www.konfrontasi.net/index.php/konfrontasi2

pertemuan berikutnya para santri diminta untuk menjelaskan isinya. Di luar itu, para santri terbiasa saling meminjamkan buku di antara mereka, khususnya buku-buku baru. Buku karangan Buya Hamka Tasawuf Modern juga dibaca Nurcholish ketika belajar di Gontor. Ia juga membaca buku-buku karangan para sarjana Barat, seperti Civilization on Trial karya sejarahwan Arnold Toynbee, dan Psikologi Pribadi karangan Fritz Kunkle.

Semasa di Gontor, Nurcholish menjadi anggota PII (Pelajar Islam Indonesia), cabang Gontor. Aktivitasnya di PII tidak terlalu banyak menyita waktu, sehingga ia tetap menekuni tugas utamanya, belajar. Untuk yang terakhir ini ia benar-benar menunjukkan prestasinya. Ia, misalnya, hanya perlu waktu lima tahun (seharusnya enam tahun) untuk menyelesaikan studinya. Waktu duduk di kelas satu, ia diizinkan untuk naik langsung ke kelas tiga, karena ia berhasil menunjukkan kemampuannya menguasai semua pelajaran kelas dua.

\section{Perihal Jenggot}

Tamat dari Gontor pada 1960, Nurcholish berencana melanjutkan kuliah ke Fakultas Kejuruan Ilmu Pendidikan (FKIP) Muhammadiyah, di Solo. Tapi rencana itu urung diwujudkan karena untuk melanjutkan kuliah ke sana, syaratnya harus punya ijazah SMA. Ketika ia menyampaikan hal itu kepada Kiai Zarkasyi, pengasuh pesantren Gontor ini berusaha membesarkan hati Nurcholish dengan menjanjikan bahwa suatu saat, kalau ada kesempatan, ia akan mengirim Nurcholish ke Mesir. Untuk sementara ini, katanya, Nurcholish mengajar saja dulu di Gontor. Nurcholish pun menuruti saran kiainya mengajar di Gontor. Dan orangtuanya tidak keberatan, sambil berharap suatu saat akan benar-benar bisa belajar di Mesir.

Berita bahwa Nurcholish akan belajar ke Mesir sudah beredar luas di kampung halaman. Orang-orang tua dan teman sebayanya senang sekaligus berharap Nurcholish akan menjadi orang pertama di kampung mereka yang belajar ke luar negeri, dan kelak pulang menjadi ulama. Namun, masalahnya, kepastian mengenai rencana itu semakin samar-samar. Nurcholish kuatir orangtuanya akan menanggung malu akibat kegagalannya pergi belajar ke Mesir. Suatu saat, ketika pulang kampung, Nurcholish memberitahu teman-temannya bahwa ia telah membatalkan rencana kepergiannya ke Mesir karena di sana ada aturan untuk memanjangkan jenggot, dan ia tidak mau. Setelah itu, ia kembali ke Pesantren Gontor untuk melanjutkan kegiatan mengajar. 